\title{
Role of impression cytology during hypovitaminosis $\mathrm{A}$
}

Istituto Di Clinica Oculistica dell' Universita' Di Genova, Italy

A Polizzi

M Schenone

$S$ C Saccà

S Burlando

Clinica Chirurgica dell' Universita' di

Genova, Italy

D Freedman

G Marinari

S Cuneo

G Camerini

Istituto Di Statistica Medica E Biometria, Italy

S Rovida

Istituto Tumori $\mathbf{D i}$ Milano, Italy

F Formelli

Correspondence to: Dr A Polizzi, Clinica Oculistica Universita, Largo Rosanna Benzi, 10, 16132 Genova, Italy.

Accepted for publication 18 September 1997

Table 1 Patient characteristics

\begin{tabular}{lll}
\hline No of patients & $\begin{array}{l}\text { Operated patients } \\
(n=48)\end{array}$ & $\begin{array}{l}\text { Control group } \\
(n=34)\end{array}$ \\
\hline $\begin{array}{l}\text { Males/females } \\
\text { Average age (range) (years) }\end{array}$ & $15 / 33$ & $11 / 23$ \\
$\begin{array}{l}\text { Patients with ocular symptoms/total no of patients } \\
\text { Average time since operation (range) }\end{array}$ & $\begin{array}{l}44(21-73) \\
\text { Percentage average weight loss }\end{array}$ & $103(24-204)$ months \\
$\begin{array}{l}\text { Patients in satisfactory protein nutritional } \\
\quad \text { condition/total no of patients }\end{array}$ & 73.4 & \\
\hline
\end{tabular}
time since operation, percentage weight loss). All the examinations were repeated after intramuscular therapy with vitamin A.

Results-Corneoconjunctival alterations visible with fluorescein and rose bengal staining were present in $67.7 \%$ of cases, impression cytology alterations in $93.7 \%$, adaptometric alterations in $82.2 \%$; vitamin A plasma levels were below normal in $\mathbf{9 5 . 8 \%}$ of cases. After the therapy with vitamin $A$ a significant reduction was found for every examination. The correlation between impression cytology and adaptometry and vitamin A plasma levels and between corneoconjunctival alterations and vitamin A plasma levels was significant. There was no significant correlation between impression cytology and nutritional condition, age time since operation, and percentage weight loss. Conclusion-These results show impression cytology is a specific indicator for hypovitaminosis A because it is not influenced by other factors related to the general condition of the patient. Many patients with hypovitaminosis A not demonstrating ocular symptoms of changes visible with fluorescein and rose bengal showed alterations with impression cytology.

Aims-Evaluation of the morphological damage to the ocular surface of patients operated for biliopancreatic diversion for pathological obesity and the correlation of impression cytology with vitamin A plasma levels, adaptometry, and other general variables.

Methods-48 patients (15 males, 33 females, age range 21-73) and 34 normal subjects were examined with fluorescein and rose bengal, a plasma dose of vitamin $A$, and adaptometry. The results of the various tests were subdivided into three levels $(0=$ normal, $1=$ moderately altered, 2 = seriously altered). The impression cytology and adaptometry results were correlated with vitamin A levels and other patient data (age, nutritional condition,

Biliopancreatic diversion (BPD) is performed in patients suffering from morbid obesity. ${ }^{1}$ This technique causes a delay of contact between biliopancreatic juices and fat starch which results in a reduction of absorption of high caloric food. ${ }^{12}$ One of the complications observed after BPD is a lack of the fat soluble vitamin $A$, accompanied by an alteration of the ocular surface associated with night blindness. ${ }^{3}$ In fact, it has been noted that vitamin A influences both the integrity of conjunctival cells and the ability to see in the dark. ${ }^{34}$ In this study we evaluated quantitatively the morphological damage affecting the ocular surface, correlating the data with plasma vitamin A levels, adaptometry, and patient data.

\section{Materials and methods}

Table 1 gives patient characteristics for subjects who underwent BPD (operated patients) and for those who did not receive (control group) any treatment. Forty eight patients undergoing BPD were referred to us because of ocular symptoms specific for hypovitaminosis A.

All patients received a visual examination which included refractive assessment, fundus examination, tonometric reading, examination of the ocular surface using fluorescein and rose bengal, and impression cytology.

Blood samples were collected from each patient and the level of plasma vitamin A assessed by using HPLC (high pressure liquid chromatography). ${ }^{5}$ Goldmann-Weeker adaptometry was performed on all patients. A control group of 34 subjects, comparable in age with those undergoing BPD, was subjected to the examinations as described above. All operated patients were re-examined 60 days after a therapy which consisted of one phial of Arovit IM (300 000 IU) per day.

The alterations that were revealed by impression cytology, biomicroscopic examination of the ocular surface, plasma vitamin A levels, and adaptometry were subdivided into three grades of severity: $0=$ no alteration/normal, $1=$ minor alterations, $2=$ major alterations.

Corneoconjunctival alterations, as revealed by biomicroscopic examination using fluorescein and rose bengal, were subdivided into the following grades: grade $0=$ absence of significant alterations; grade $1=$ translucent appearance of the conjunctiva (pre-Bitot spots) with 


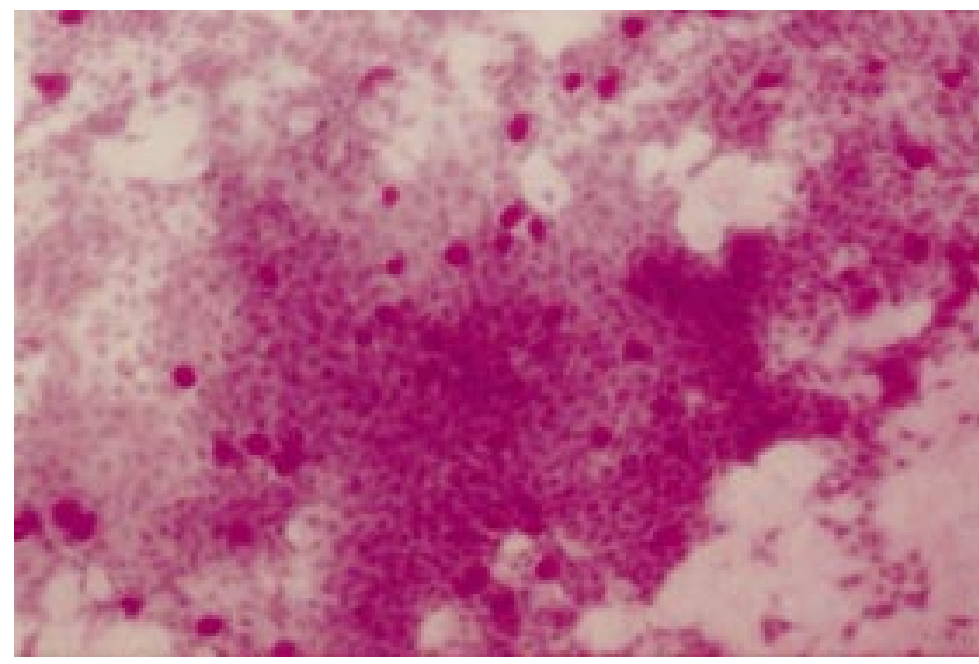

Figure 1 Impression cytology (grade 0) performed in the upper temporal bulbar conjunctiva, of a 44 year old man, 6 months after BPD surgery: numerous epithelial normal cells and mucous cells positive for periodic acid Schiff, Papanicolaou staining (goblet cells) (original magnification $\times 25$ ).

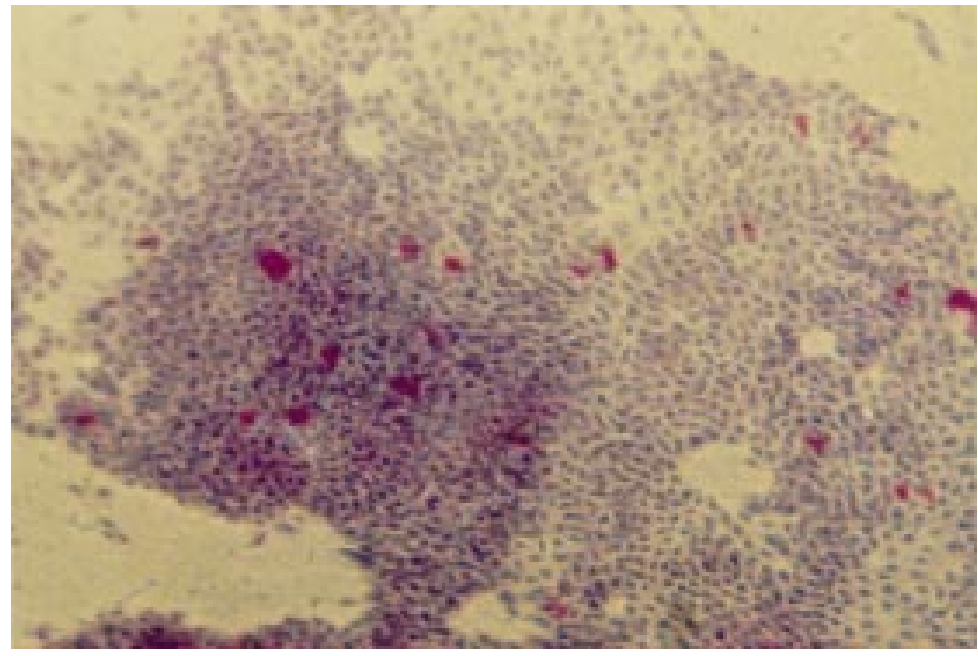

Figure 2 Impression cytology (grade 1) performed in the upper temporal bulbar conjunctiva, of a 40 year old woman, 36 months after BPD surgery. A single layer of polygonal epithelial cells with cytoplasmic edges well defined. Rare goblet cells (compared with grade 0), marked reduction of "goblet cells" (original magnification $\times 25$ ).

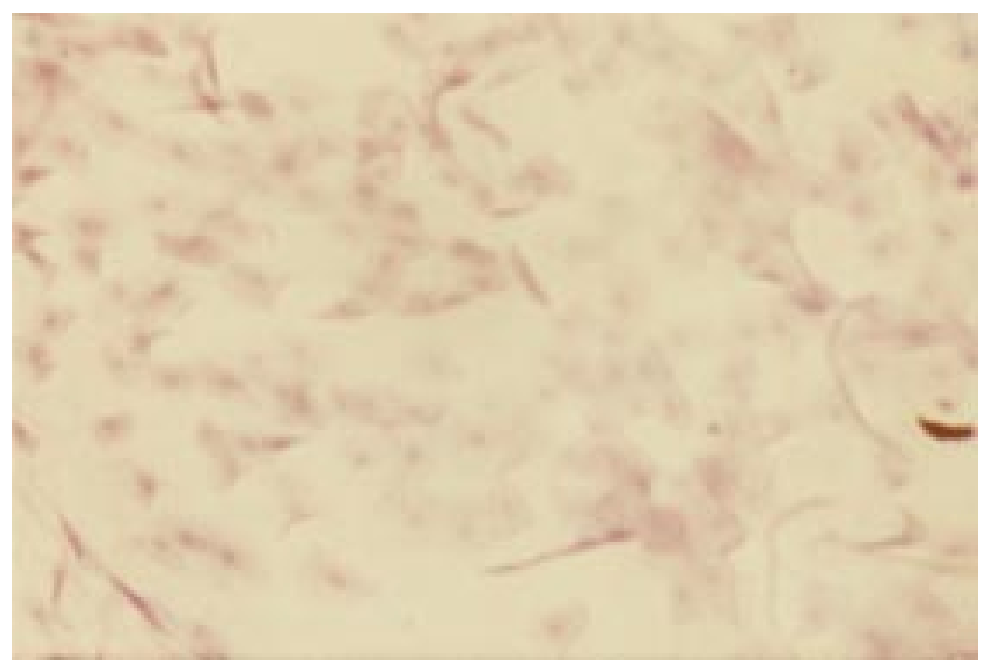

Figure 3 Impression cytology (grade 2) performed in the lower temporal bulbar conjunctiva, of a 48 year old woman, 58 months after BPD surgery. Epithelial cells with evident squamous features, less cohesivity, folded cytoplasmic edges (squamous metaplasia), absence of "goblet cells" (original magnification $\times 40$ ).
Table 2 Corneal conjunctival alterations (biomicroscopic observations by staining with fuorescein and bengal rose)

\begin{tabular}{llrl}
\hline & \multicolumn{2}{l}{ Patients } & \\
\cline { 2 - 3 } Grade & $T_{0}$ & $\begin{array}{l}T_{1} \text { (after 60 days } \\
\text { of therapy) }\end{array}$ & Control group \\
\hline 0 & $16(33.3 \%)$ & $25(52.1 \%)$ & $33(97 \%)$ \\
1 & $24(59 \%)$ & $16(33.3 \%)$ & $1(3 \%)$ \\
2 & $8(16.7 \%)$ & $7(14.6 \%)$ & \\
\hline
\end{tabular}

Table 3 Impression cytology

\begin{tabular}{lccc}
\hline & \multicolumn{2}{l}{ Patients } & \\
\cline { 2 - 3 } Grade & $T_{0}$ & $\begin{array}{c}T_{1} \text { (after 60 days } \\
\text { of therapy) }\end{array}$ & Control group \\
\hline 0 & $3(6.3 \%)$ & $16(33.3 \%)$ & $33(97 \%)$ \\
1 & $25(52 \%)$ & $23(47.9 \%)$ & $1(3 \%)$ \\
2 & $20(41.7 \%)$ & $9(18.8 \%)$ & \\
\hline
\end{tabular}

or without slight keratoconjunctivitis punctata which was more evident in the inferior portion of the cornea, fluorescein, and rose bengal coloured zones; grade 2 =foamy formations in the conjunctiva (Bitot spots) and keratoconjunctivitis punctata with large coloured areas.

The results of impression cytology were subdivided into the following grades: grade $0=$ numerous mucous cells $(200$ per field/ $\mathrm{mm}^{2}$ ), epithelial cells with regular borders (Fig 1) (nucleus/cytoplasm (N/C) ratio 1:1, 1:2); grade 1: few goblet cells (50-200 per field), drops of mucus, epithelial cells some undergoing desquamation (Fig 2); grade 2: goblet cells less than 50 per field $/ \mathrm{mm}^{2}$; epithelial cells with irregular borders undergoing desquamation (N/C ratio 1:4, 1:5 (squamous metaplasia) (Fig 3). ${ }^{6}$

Adaptometric alterations were also subdivided into three grades: grade $0=$ absolute threshold 3.5 LU picostilb, grade $1=$ absolute threshold 3.5-5.5 LU picostilb; grade 2=absolute threshold 5.5 LU picostilb.

Finally, plasma vitamin A levels were divided into three grades: grade $0, \geqslant 500 \mathrm{ng} / \mathrm{ml}$; grade $1,150-500 \mathrm{ng} / \mathrm{ml}$; grade $2, \leqslant 150 \mathrm{ng} / \mathrm{ml}$.

We subsequently correlated statistically the results of impression cytology with those of adaptometry, vitamin A plasma levels, and other patient data such as protein nutrition status (serum total protein, albumin, transferrin) number of days since operation, weight loss, and ocular symptoms. The independent ANOVA data test was used for statistical analysis.

\section{Results}

Patients who underwent BPD had ocular surface alterations as evidenced by biomicroscope observation (Table 2), abnormal impression cytology (Table 3), pathological adaptometric curves (Table 4), and low levels of plasma vitamin A (Table 5). These alterations were more evident before Arovit therapy, although they persisted to a certain degree even after therapy.

The plasma vitamin A level of BPD patients were correlated in statistically significant way with the results of impression cytology, staining of the corneoconjunctival surface, and adaptometry results (Table 6). The percentage 
Table 4 Adaptometry

\begin{tabular}{lccc}
\hline & \multicolumn{2}{l}{ Patients } & \\
\cline { 2 - 3 } Grade & $T_{0}$ & $\begin{array}{c}T_{1} \text { (after 60 days } \\
\text { of therapy) }\end{array}$ & Control group \\
\hline 0 & $9(18.8 \%)$ & $13(27.1 \%)$ & $32(98.5 \%)$ \\
1 & $24(52 \%)$ & $27(56.2 \%)$ & $2(1.5 \%)$ \\
2 & $15(31.2 \%)$ & $8(16.7 \%)$ & \\
\hline
\end{tabular}

Table 5 Plasma vitamin A levels ( $\mathrm{ng} / \mathrm{ml})$

\begin{tabular}{lccc}
\hline & \multicolumn{2}{c}{ Patients } & \\
\cline { 2 - 3 } Grade & $T_{0}$ & $\begin{array}{l}T_{1} \text { (after 60 days of } \\
\text { therapy) }\end{array}$ & Control group \\
\hline 0 & $2(4.2 \%)$ & $16(33.3 \%)$ & $34(100 \%)$ \\
1 & $23(47.9 \%)$ & $\begin{array}{c}26(54.2 \%) \\
6(12 . .5 \%)\end{array}$ & \\
2 & $23(47.9 \%)$ & $6(10 \%)$ & \\
\hline
\end{tabular}

Table 6 Comparison of results before and after therapy with vitamin $A$ (Wilcoxon test)

\begin{tabular}{ll}
\hline Examination & p Value \\
\hline Biomicroscopic observation & $<0.05$ \\
Impression cytology & $<0.0001$ \\
Adaptometry & $<0.01$ \\
Plasma vitamin A levels & $<0.0001$ \\
\hline
\end{tabular}

Table 7 Statistical correlation

\begin{tabular}{ll}
\hline Type of correlation (before and after therapy) & p Value \\
\hline Impression cytology/plasma vitamin A level & $<0.0001$ \\
Impression cytology/adaptometry & $<0.0001$ \\
Adaptometry/plasma vitamin A level & $<0.0001$ \\
Corneoconjunctival alteration/plasma vitamin A & \\
$\quad$ level & $<0.01$ \\
Impression cytology/age & $\mathrm{NS}$ \\
Impression cytology/nutritional status & $\mathrm{NS}$ \\
Impression cytology/time since surgery & $\mathrm{NS}$ \\
Impression cytology/percentage weight loss & $\mathrm{NS}$ \\
Impression cytology/ocular symptoms & $\mathrm{NS}$ \\
\hline
\end{tabular}

weight loss, nutritional protein status, number of days since operation, and patient age did not appear to be statistically correlated with the results of impression cytology (Table 7).

\section{Discussion}

The alterations of the ocular surface observed in our study are similar to those described as symptoms of nutritional polydeficiency syndromes. Such symptoms during malnutrition are today only found in Third World countries. $^{7-9}$ Since $1925,{ }^{10}$ vitamin A has been considered essential for cellular differentiation and for the maintenance of the epithelial cells of mucous membranes. Vitamin A deficiency and, therefore, the consequences of squamous metaplasia have been ascribed as the cause of the majority of lesions observed on the ocular surface. The sample population examined in our study revealed a deficiency syndrome which was clearly due to the lack of vitamin A, as demonstrated according to observation at various times. ${ }^{10} 11$ Furthermore, it was noted that the level of deficiencies was not related to patient age. ${ }^{12}$ The findings of this study which concerns adult patients, were found to be similar to those reported in children of the Third World. Moreover, the relation between aging and impression cytology does not allow the prediction of keratinisation or the absence of mucous cells. On the other hand, plasma vitamin A levels and adaptometric results are strictly correlated. Such a correlation does not exist between the results of impression cytology, nutritional protein status, and the amount of time elapsed since the operation. This may indicate the presence of an individual compensatory mechanism during cellular membrane vitamin A deficiency (individual capacity to draw upon vitamin A deposits, most of which are available as retinol binding protein) or may suggest that other fat soluble vitamins are drawn upon as a response to vitamin $\mathrm{A}$ deficiency. Vitamin E, for example, acts as an antioxidant and is very important in the prevention of epithelial damage by free radicals. This study did not take into consideration the role of vitamin $\mathrm{E}$. In every case, plasma vitamin A levels were more strictly correlated with impression cytology than they were with the appearance of the corneoconjunctival surface biomicroscopic observations. On the other hand, it has been noted that the corneal epithelium undergoes modifications which precede the development of keratoconjunctivitis punctata. This observation explains why the results of impression cytology in many of our patients revealed severe alterations, even though the patients did not complain of any symptoms. Our study confirms the role of impression cytology during follow up examinations in patients affected with vitamin A deficiency as a valuable means of providing a more sensitive index in comparison with biomicroscopic examination using fluorescein or rose bengal. Impression cytology is easy and cheap. Furthermore, impression cytology is not influenced by factors related to general patient health, and provides an effective mean of demonstrating alterations which precede the symptoms of corneoconjunctivitis.

1 Scopinaro N, Giannetta E, Adami GF, et al. Biliopancreatic diversion for obesity at eighteen years. Surgery 996;119:261-8.

2 Scopinaro N, Giannetta E, Civalleri D, et al. Partial and total biliopancreatic by-pass in the surgical treatment of obesity. Int f Obesity 1981;22:421-9.

3 Marmor MF. Clinical physiology of the retina. In: Peyman GA, Sanders DR, Goldberg MF, eds. Principles and practice of ophthalmology. Philadelphia: Saunders 1990:823-56.

4 Wolf G. Multiple function of vitamin A. Physiol Rev 1984;64:879-937.

5 Catignani GL, Bieri JG. Simultaneous determination of retinol and tocopherol in serum or plasma by liquid chromatography. Clin Chem 1985;29:708-12.

6 Tseng SC. Staging of conjunctival squamous metaplasia by impression cytology. Ophthalmology 1985;92:728-33.

7 Wittpen JR, Tseng SCG, Sommer A. Detection of early xerophthalmia by impression cytology. Arch Ophthalmol 1986;104:237-9.

8 Resnikoff S, Luzfau R, Filliard G, et al. Impression cytology with transfer in xerophthalmia and conjunctival disease. Int Ophthalmol 1992;16:445-51.

9 Natadisastra G, Wittpenn JR, Muhilo C, et al. Impression cytology: a practical index of vitamin A status. Am $\mathcal{f}$ Clin Nutr 1988;48:695-701.

10 Polizzi A, Burlando S, Calabria G. Lesioni corneocongiuntivali ed emeralopia in portatori di by-pass intestinale. Atti Soc Oftalmol Lombarda 1981;36:59-64.

11 Polizzi A, Panarello SM, Brezzo MV, et al. Studio della superficie oculare in pazienti operati di by-pass per obesità patologica. Boll Ocul 1987;66(Suppl 5):33-5.

12 Rolando $M$, Terragna FM, Burlando S, Zingirian $M$. Valutazione mediante citologia ad impressione dell'effetto dell'invecchiamento sulla superficie oculare. Atti Soc Oftalmol Lombarda 1985;40:187-90. 